\title{
Articles
}

Central European Review of Economics \& Finance

Vol. 19, No. 3 (2017), pp. 5-17. D0I: 10.24136/ceref.2017.009

Wojciech Sońta ${ }^{1}$

\section{EMISSION OF POLLUTIONS AND AIR PROTECTION ON THE CZECH-POLISH BORDER}

The international community decided that the global temperature cannot rise more than $2^{\circ} \mathrm{C}$ comparing with the level before the period of industrialisation that the climate changes do not reach a dangerous level. Therefore, EU endeavours to induce the member countries to reduce the emissions. In turn, each of the countries in various areas of functioning of their economies and households seeks reduction of harmful emissions having influence on increase of the temperature in the local scale. In this article there is taken an attempt to present the problem based on the example of the Czech-Polish border and especially on the terrain of Cieszyn city.

JEL Classification Codes: F65, G11, N90, Q53.

Keywords: climate policy, air pollution, natural environment protection, cogeneration.

\section{Introduction}

In the era of the global economic slowdown and the European debt crisis more often appears a question about a sense of the EU climate policy. However, the most influential politicians of the world (A. Merkel, B. Obama) express their view on various world forums (e.g. G7 summit) that the world must unite in actions preventing climate changes. Implementing significant limitations of using fossil fuels and emission of $\mathrm{CO}_{2}$ by the Union will distinctly affect cooling of the climate. The purpose of the article is presentation and analysis of actions aiming to reduce of air pollution at the border terrain of Cieszyn city. It seems that analysis of the case will allow recognising of the

\footnotetext{
${ }^{1}$ Associate Professor PhD., University of Technology and Humanities K. Pulaski in Radom, Poland, Faculty of Economics, Departament of Finance and Insurance.
} 
problem in the local scale according to the principle: „act locally, think globally". There was used in the article the method of analysis and synthesis of occurring changes and processes in years 2010 - 2014 in terms of air pollution's reduction on the terrain of Cieszyn city. At the end of the article it was presented a vision of further progress of actions having as a goal reduction of emission of pollution to the atmosphere.

\section{Characteristic of the study area}

Length of the border between the Czech Republic and the Republic of Poland is 796 kilometres. Program's area of environmental protection covers about 7.1 million citizens and on the Czech side there are 3.4 million while on the Polish side there are 3.7 million. Density of the population of the individual parts of the area is above average value for the whole EU. Total density of the population in the area of support is 151 citizens $/ \mathrm{km}^{2}$. Main reason of the increased migration on the area are economic factors (decrease of workplaces, structural problems of the mining industry). In turn, constantly ongoing process of suburbanisation has influence on internal migration. According to the condition dated $31^{\text {st }}$ December 2014 average unemployment rate on the Czech side is $8.7 \%$ while on Polish side is $14.9 \%$. The borderland has also development potential in service sector, it means services related to tourism and health resort. The border areas are characterised by a variety of natural wealth which are numerous mountain massifs, relatively good quality of the environment and vast areas being protected. Condition of atmospheric air in various parts is different. The settlement structure has direct influence on spatial distribution of air quality as well presence of pollutants which are related with localisation of main stationary sources, first of all these are industrial companies and also households. The main transport routes are referred to the settlement structure and are related with the highest occurrence of pollution.

Summarizing the above mentioned arguments related with characteristics of the studied area it must be claimed that zones having larger grade of pollution which the Silesia province is divided have negative impact on the neighbouring zones with lower grade of pollution because as it was stated in the further part of the study „air does not know boundaries”. Therefore it would be a mistake to consider the problem in isolation from the wider environment hence it was stated as a basis for the analysis not only Cieszyn but also the Silesia province. Specifics of the province are characterised by 
the fact that on its terrain there is concentration of different pollutants not only the air and between them there are interactions having influence on the whole environment.

In turn, Cieszyn city is located on the river Olza where its right part of the bank belongs to Poland and left part to the Czech Republic and it is called Czech Cieszyn. In the Polish part there are 36.1 thousand of citizens on the area of $28.6 \mathrm{~km}^{2}$, the Czech part has 24.4 thousand of citizens and $34.4 \mathrm{~m}^{2}$. Cieszyn is located in southern part of the Silesia province and it is a county city. Density of the population is 1262 persons $/ \mathrm{km}^{2}$. Increase of the population in the Cieszyn county is +271 people (Dzieje Cieszyna..., 2010).

The city is an important administrative, cultural and educational centre. It is also nodal point of transport on the map of Europe. In the city there is also headquarter of Cieszyn Silesia Euro-region. It becomes more popular tourist and cultural centre what partially compensates collapse of the local industry in the 90s of the last century and lack of large economic investments. The local economy is currently focused mainly on trade and services. Cieszyn is a city with plenty of green areas (23\% of the city area) what is not without significance for environmental protection. System of urban roads is well developed what causes that Cieszyn has its own public transport which operates budget company of the city, i.e. 9 bus lines ( 5 urban and 4 suburban) (Sońta, 2008).

Summarizing the above mentioned it must be claimed that the happening structural changes in the city follow in the right direction what definitely will transfer into reduction of air pollution. Inflow of funds from EU which will contribute to eliminate the old technology, modernization of the infrastructure, etc. will also help.

There are two cities in one municipal body but in two different countries. It is typical phenomenon for cities located on borderlands territories. History was not so kind for them because the boundary was moved in one or other side and not local communities but politicians decided about the division. Nonetheless, the time obliterated trauma from the past and currently co-operation develops very well in different fields and only the air as a free good flows naturally from one side of the border to the other depending on direction of a wind. It is interesting why the air as a free good derived from the nature and occurring in unlimited amount is so polluted? 


\section{Actual condition of air pollution in the Silesia province}

In 2014 on the terrain of the Silesia province operated 325 plants especially burdensome for cleanness of the air, i.e. $18.2 \%$ of the total number of this type of plants in Poland. The plants had emitted to the atmosphere dust, gas pollution or together dust and gas ones. Emission of the dust and gas pollution in the Silesia province from the plants especially burdensome for cleanness of the air in 2014 was 37265.7 thousands of tons, including 734.2 thousands of tons without carbon dioxide (Directive 2001/80/WE). In 2014 there were emitted 10.3 thousands of tons of dust pollution ( 0.8 ton per $1 \mathrm{~km}^{2}$ of the area) what was $21.7 \%$ of domestic dust emission (in Poland 0.2 ton per $1 \mathrm{~km}^{2}$ ). Emission of the dust pollution in the province decreased by $3.2 \%$ comparing with the previous year. The largest amount of dust pollution was generated by burning of fuels $(46.7 \%$ of the general emission of the dusts in the province). The largest amount of dust pollution was emitted in Dabrowa Gornicza and it was 4.0 thousands of tons (what represents $39.4 \%$ of the general emission in the province) and in Rybnik with 1.1 thousands of tons $(10.4 \%)$. In relation to 2005 emission of the pollution was reduced by half, i.e. $54.3 \%$.

Among the emitted gas pollutants in the Silesia province dominated carbon dioxide being $98.1 \%$ of the global emission of gases on the terrain. Emission of the gas pollutants (excluding carbon dioxide) was 724.0 thousands of tons (58.7 tons per $1 \mathrm{~km}^{2}$ of the area) what represents $46.0 \%$ of the national emission (in Poland 5.0 tons per $\mathrm{km}^{2}$ ). Comparing with year 2013 there was noticed increase of emission of the gas pollutants by $1.3 \%$ (excluding carbon dioxide). The largest share in emission of the gas pollutants (excluding carbon dioxide) had methane $60.9 \%$, carbon monoxide $21.8 \%$ and Sulphur dioxide $9.4 \%$. The largest emission of the gas pollutants (excluding carbon dioxide) was noticed in Dabrowa Gornicza and it was 154.3 thousands of tons (21.3\% of the general emission in the province) and in the Pszczyna county $88.8 \%$ thousands of tons (12.3\%). During the last 10 years emission of the gas pollutants (excluding carbon dioxide) had fluctuations: the lowest emission was noticed in 2009 (644.9 thousands of tons) and the highest in 2007 (754.1 thousands of tons).

Among the plants which are especially burdensome 222 had devices to reduce the dust pollutants $(68.3 \%$ of the total number of the especially burdensome plants in the province) and only 53 had devices to reduce the gas pollutants (16.3\%). In the devices to reduce pollution of the air in the Silesia province were blocked and neutralised 2749.4 thousands of tons of the dust pollutants what is $99.6 \%$ of the generated dust pollutants and 274.3 
thousands of tons of the gas pollutions what is $27.5 \%$ of the generated gas pollutants (excluding carbon dioxide). Degree of reduction of the generated dust pollutants in years 2005 - 2014 remained at the high level (more than $99 \%$ ), however in case of the gas pollutants it was fluctuating (in the range between $27.5 \%$ a $31.8 \%$ ).

According (to the article 87 dated $27^{\text {th }}$ April 2001 Environmental protection law) evaluations are done in zones including agglomerations. On the terrain of the Silesia province there are separated 5 zones according to (regulation of Minister of Environment dated 10th August 2012 regarding zones where there is done evaluation of the air quality). These zones are as follows: Upper Silesia, Rybnik-Jastrzab, Bielsko-Biala city, Czestochowa city and Silesia zone. The evaluation of the air quality and observations of changes were done under national environment monitoring (article 88 of the act of Environmental protection law). The basis for classification of the zones according to the article 89 of the above mentioned act were admissible levels of substances in the air and admissible levels having tolerance margin with allowed cases of exceeding, target levels and levels of long-term goals due to the protection of human health and protection of plants. List of the pollutants in terms of fulfilment of the criteria defined to protect healthcare covered: benzene, nitrogen dioxide, Sulphur dioxide, carbon monoxide, ozone, dust particulates PM 10, dust particulates PM 2.5, arsenic, benzopyrene, lead, cadmium and nickel. For all the substances being assessed the zones were included to one of the classes: class A - if concentrations of the pollutants on its area did not exceed respectively the acceptable levels, class $C$ - if concentrations of the pollutants on its area exceeded the acceptable levels.

\section{Evaluation of air pollutions' condition in Cieszyn based on the selected indicators}

Starting the analysis of the selected indicators for the Cieszyn city it should be realised how the concept of environment protection should be understood. Air protection relies on reducing and keeping levels of the substances in the air below acceptable, target levels or levels of long-term goals (Kaczmarczyk 2015). All kinds of the mentioned groups of indicators in the analysis will be included with the proviso that indicators for the Cieszyn city will be compared to the highest in the other measurements places of the Silesia zone. In this way we want to present existing differences between the places of the measurements and the same their evaluation with respect to the acceptable levels and levels of maximum pollution in other measurement places. 
Table 1. Maximum 8-hour concentration of carbon monoxide in the years 2011-2014 (admissible value $\left.10 \mu \mathrm{g} / \mathrm{m}^{3}\right)$

\begin{tabular}{|l|c|c|c|c|}
\hline \multicolumn{1}{|c|}{ Place of measurement } & $\mathbf{2 0 1 1}$ & $\mathbf{2 0 1 2}$ & $\mathbf{2 0 1 3}$ & $\mathbf{2 0 1 4}$ \\
\hline Cieszyn & 3,3 & 4,2 & 2,2 & 3,7 \\
\hline Wodzisław & 6,1 & 7,5 & 3,0 & 3,0 \\
\hline
\end{tabular}

Source: http// www. katowice/pios.gov.pl/monitoring/raporty/

Table 2. Results of maximum 24-hour concentration of Sulphur dioxide in $\mu \mathrm{g} / \mathrm{m}^{3}$ on the measurement stations in the years 2010 - 2014 and classification of the zones in 2014 in respect of protection of human health (acceptable level for 24 -hour concentrations is $125 \mu \mathrm{g} / \mathrm{m}^{3}$ )

\begin{tabular}{|l|c|c|c|c|c|}
\hline \multicolumn{1}{|c|}{ Place of measurement } & $\mathbf{2 0 1 0}$ & $\mathbf{2 0 1 1}$ & $\mathbf{2 0 1 2}$ & $\mathbf{2 0 1 3}$ & $\mathbf{2 0 1 4}$ \\
\hline Cieszyn & 198 & 65 & 85 & 49 & 73 \\
\hline Zywiec & 256 & 145 & 193 & 153 & 132 \\
\hline
\end{tabular}

Source: as in the table 1.

Table 3. Results of annual average concentrations of nitrogen dioxide in $\mu \mathrm{g} / \mathrm{m}^{3}$ on the measurement stations in the years 2010 - 2014 and classification of the zones in 2014 in respect of protection of human health (acceptable level is $40 \mu \mathrm{g} / \mathrm{m}^{3}$ )

\begin{tabular}{|l|c|c|c|c|c|}
\hline \multicolumn{1}{|c|}{ Place of measurement } & $\mathbf{2 0 1 0}$ & $\mathbf{2 0 1 1}$ & $\mathbf{2 0 1 2}$ & $\mathbf{2 0 1 3}$ & $\mathbf{2 0 1 4}$ \\
\hline Cieszyn & 20 & 17 & 17 & 17 & 15 \\
\hline Wodzisław & 28 & 25 & 23 & 21 & 20 \\
\hline
\end{tabular}

Source: as in the table 1.

Table 4. Results of maximum 8-hour concentration on the measurement stations in the years 2010 - 2014 and classification of the zones for ozone in 2014 in respect of protection of human health as a long-term goal (measurement of long-term goals $120 \mu \mathrm{g} / \mathrm{m}^{3}$ )

\begin{tabular}{|l|c|c|c|c|c|}
\hline \multicolumn{1}{|c|}{ Place of measurement } & $\mathbf{2 0 1 0}$ & $\mathbf{2 0 1 1}$ & $\mathbf{2 0 1 2}$ & $\mathbf{2 0 1 3}$ & $\mathbf{2 0 1 4}$ \\
\hline Cieszyn & - & 149 & 154 & 166 & 153 \\
\hline Złoty Potok & 152 & 146 & 165 & 164 & 149 \\
\hline
\end{tabular}

Source: as in the table 1.

Table 5. Results of acceptable frequency of 8-hour concentrations' exceedance on the measurement stations in the years 2008-2014 and classification of the zones for ozone in 2014 in respect of protection of human health (acceptable frequency of exceeding is 25 days)

\begin{tabular}{|l|c|c|c|c|c|}
\hline \multicolumn{1}{|c|}{ Place of measurement } & 2008-2010 & 2009-2011 & 2010-2012 & 2011-2013 & 2012-2014 \\
\hline Cieszyn & - & 23 & 30 & 27 & 22 \\
\hline Zloty Potok & 26 & 24 & 30 & 32 & 28 \\
\hline
\end{tabular}

Source: as in the table 1. 
Table 6. Results of annual average concentrations of dust particulates PM $10 \mathrm{in} \mu \mathrm{g} / \mathrm{m}^{3}$ on the measurement stations in the years 2010-2014 and classification of the zones in 2014 in respect of protection of people (acceptable level $40 \mu \mathrm{g} / \mathrm{m}^{3}$ in consideration of the acceptable frequency of exceeding the level of 24-hour concentrations)

\begin{tabular}{|l|c|c|c|c|c|}
\hline \multicolumn{1}{|c|}{ Place of measurement } & $\mathbf{2 0 1 0}$ & $\mathbf{2 0 1 1}$ & $\mathbf{2 0 1 2}$ & $\mathbf{2 0 1 3}$ & $\mathbf{2 0 1 4}$ \\
\hline Cieszyn & 35 & 37 & 36 & 36 & 37 \\
\hline Wodzislaw & 80 & 63 & 78 & 57 & 53 \\
\hline
\end{tabular}

Source: as in the table 1.

Table 7. Frequency of exceedances of the acceptable 24-hour concentration's level of dust particulates PM 10 in the years 2012 - 2014 (number of acceptable exceeding is 35)

\begin{tabular}{|l|c|c|c|}
\hline \multicolumn{1}{|c|}{ Place of measurement } & 2012 & 2013 & 2014 \\
\hline Cieszyn & 50 & 50 & 63 \\
\hline Wodzislaw & 170 & 145 & 135 \\
\hline
\end{tabular}

Source: as in the table 1.

Table 8. Number of acceptable exceedances of the 24-hour concentrations' level of dust particulates PM 10 in the years 2012 - 2014 and measurements' time coverage in percentages in 2014 (90\%)

\begin{tabular}{|l|c|c|c|}
\hline \multicolumn{1}{|c|}{ Place of measurement } & $\mathbf{2 0 1 2}$ & $\mathbf{2 0 1 3}$ & $\mathbf{2 0 1 4}$ \\
\hline Cieszyn & 50 & 50 & 63 \\
\hline Pszczyna & 90 & 140 & 138 \\
\hline
\end{tabular}

Source: as in the table 1.

Table 9. 90.4 percentile of 24-hour concentrations of dust particulates PM 10 in the years 2010 - 2014 (acceptable level is $50 \mu \mathrm{g} / \mathrm{m}^{3}$ )

\begin{tabular}{|l|c|c|c|}
\hline \multicolumn{1}{|c|}{ Place of measurement } & $\mathbf{2 0 1 2}$ & $\mathbf{2 0 1 3}$ & $\mathbf{2 0 1 4}$ \\
\hline Cieszyn & 80 & 70 & 67 \\
\hline Wodzislaw & 160 & 120 & 110 \\
\hline
\end{tabular}

Source: as in the table 1.

Doing the evaluation of the presented indicators in the tables from 1 to 9 it should be claimed that the situation in terms of air pollution affecting health of the people and animals and protection of plants in Cieszyn is satisfactory in relation to other measurement's places in the Silesia zone.

It is evidenced in the fact that:

- most of the indicators is much below the acceptable ones, 
- indicators of the Cieszyn city in comparison to other places where there were stated maximum pollutions are usually twice and even in some cases three times less.

It is a premise to calm our southern neighbours but it is never so good in order to be even better.

\section{Environmentally friendly activities in Cieszyn}

The Kawka program is a common program realised by the National Fund of Environmental Protection and Water Management (NFEP\&WM) and the Provincial Fund of Environmental Protection and Water Management (PFEP\&WM) which aim is to reduce emission of the pollutants to the atmospheric air.

Cities having more than 10.000 inhabitants and resorts where there are noticed exceedances of the accepted levels of air pollution (PM 10 dust and benzopyrene) can apply for money in accordance with Kawka program.

Realisation in 2015 the task „Reduction of low emission in the City Centre of Cieszyn - pilot project" relied on exchange of old heating technologies in the buildings into more energetic and ecological, it means connecting the buildings equipped with individual coal stoves to urban heating system. In addition, installation of thermal insulation in the buildings so far uninsulated will cause reduction of energy demand needed for their heating.

The main sources of air pollution in the cities are local heat sources, especially households' coal stoves and urban transport. The aim of the Kawka program is reduction of the pollution levels, first of all PM 2.5 and PM 10 dusts and emissions of carbon dioxide.

Financial funds which the city received for the purpose are: 1 million and 13 thousand Polish zlotych, including 444 thousand Polish zlotych of grant from the NFEP\&WM, 386 thousand Polish zlotych of loan from the NFEP\&WM and 183 thousand Polish zlotych of loan from the PFEP\&WM. There is possible to get subsidy in the form of grants as $45 \%$ of the funds from the NFEP\&WM and a loan up to $35 \%$ of the funds from the PFEP\&WM in Katowice from the program.

The above obtained funds were distributed for the following tasks:

- there were connected to the urban heating system 8 multi-family houses,

- there were eliminated 151 coal-fired tiled stoves,

- the buildings were insulated reducing heating costs.

As a result of the investment's realisation there will be reduction of the harmful substances in Cieszyn with the values presented in the below table. 
Table 10. Reduction of the pollutants' emission in the particular groups in $\mathrm{kg} / \mathrm{year}$

\begin{tabular}{|l|c|}
\hline \multicolumn{1}{|c|}{ Types of pollutants } & Reduction of the emission \\
\hline PM 10 dust & 2264,00 \\
\hline PM 2.5 dust & 2145,00 \\
\hline Sulphur dioxide $\mathrm{SO}_{2}$ & 5362,00 \\
\hline Nitrogen oxide $\mathrm{NO}_{x}$ & 775,00 \\
\hline Carbon dioxide $\mathrm{CO}_{2}$ & 312621,00 \\
\hline Benzopyrene & 1,61 \\
\hline
\end{tabular}

Source: www.ec.cieszyn.pl

The air polluted by the gases and dusts gets inside human's body causing cardiovascular diseases, allergies, neoplastic diseases, asthmas. Benzopyrene is dangerous for a human being the same as carbon monoxide $\mathrm{CO}$ (choke-damp) which is a gas having specific properties: highly toxic, colourless, odourless and lighter than air what makes it easy to spreading. Cieszyn Power Engineering Limited Liability Company is a manufacturer and distributor of thermal and electric energy on the terrain of the Cieszyn city. The heat production is realised in high-efficiency cogeneration with production of the electric energy. The company has effective heating system what means that $75 \%$ of the produced heat comes from cogeneration (Directive 2004/8/WE).

The carried on investments in the period 2011 - 2014 when Cieszyn Power Engineering was realising the project named "Reconstruction of the heating system in Cieszyn" which was co-financed by EU influenced on such good results. The total value of the project was 30.728 thousand Polish zloty and value of the subsidy was 11.897 thousand Polish zloty. Within the investment there was done replacement of old channel system and overhead parts into new ones and replacement of thermal insulation on the existing pipelines. In relation to the investment there were modernised about 10 kilometres of the heating system what affected on reduction of heat loss and consequently limitation of the air pollution by about $9.6 \%$. Liquidation of the old heating system, mainly in the region of Bobrowka river contributed to improvement of attractiveness of the city by increasing its landscape values. Currently the company is not on the list of burdensome businesses for the natural environment.

Summing up as a result of the realised modernization Cieszyn Power Engineering became a modern and unique power plant in the field of production in Polish scale. In the longer term the company plans to replace section of the system done in old technologies into pipelines made in pre-insulated 
technology with thicker insulation. As an effect of the project there will be reduction of heat losses. Limitation of carbon dioxide emission to the atmosphere is also linked with the savings.

1. The advantages of the realised pro-ecological investments are the following (http//euroregions.org./files/dokuments/Analiza.../).

2. Ecological effect - reduction of the low emission in the city centre in Cieszyn including limitation of burdensome smog in the winter period, 323 tons of pollutants less during the year.

3. Improvement of health condition of the inhabitants and improvement of rest necessary for good health and psyche which in the winter time is limited to work related to hating of homes.

4. Increase of thermal comfort in the homes and its providing with completive prices in relation to prices of other sources.

5. Limitation of costs related to management of the buildings due to maintenance and repairs of the tile stoves, chimney maintenances and necessity of their adaptation to transporting of exhausts from gas boilers (chimney and ventilation liners).

6. Improvement of aesthetics of the buildings' facades in the centre of Cieszyn (reduction of dirt as a result of limitation of the dusts emission).

7. Safety of heat supply to the houses, elimination of danger of carbon monoxide poisoning, explosion, electric shock or fire.

8. Saving of space as a result of lack of necessity to economise surface to store of fuel and heating devices.

9. Convenience related to maintenance-free, supplier of heat provides complex maintenance, modernisation and repairs of the heating devices.

10. Possibility to obtain significant financial resources from the funds of environment protection in the form of low-interest loans or non-refundable subsidies.

"Air without borders" is the next cross-border project realised in a broad partnership in the area of Silesia Cieszyn Euro region - Těšinské Slezsko. Its goal is increasing of awareness of air quality and related to it responsibility to each other and the neighbours. The cities Cieszyn, Český Těšin and Cieszyn County and the parties of the agreement joined to its realisation. They act inter alia by informing of Polish and Czech public opinion about current status of the air pollutions and about possibilities of active participation of the residents in local actions to improve its quality, actively engaging local governments, schools and other interested institutions. The partners aim to create conditions of common monitoring of the air quality in the region of Silesia Cieszyn Euro region. The program refers to the Air Silesia one realised 
in the previous years which the object was creation of regional system of information about air quality on area of border in the region of Upper Silesia and Northern Moravia. From the above mentioned follows that in the first stage there was focused on social education and in the subsequent stages it is planned specific investments which will affect on improvement of the air condition, i.e. creation of a fund to financing exchange of boilers, heating systems and thermos-modernisation and also installation of air monitoring.

\section{Differences and barriers of Czech-Polish cross-border's cooperation}

Due to the strict norms in relation to the EU requirements the companies on the terrain of Poland and Czech Republic are forced to investments aiming to eliminate harmful impact of their business on the natural environment - removal of dust, elimination of harmful emissions. The investments have direct influence on development of the industry often due to rigorous conditions, which influence on moving the business on the terrain of other country, i.e. on the territory of Poland, where the norms are less rigorous. The most affected area is first of all the east part of Moravia-Silesian country where the limitations have significant influence on the industrial production which is an important branch of the industry in Ostrava agglomeration. A significant source of the pollution is also Upper Silesia agglomeration in which there are not such rigorous requirements as it is on the Czech side.

For example, in order to compare there will be presented a twin company named Arcelor Mittal Poland for which there was determined limit of dust emission in the amount $100 \mathrm{\mu g} / \mathrm{m}^{3}$ emission of the pollution. Whereas, Arcelor Mittal Ostrava under the same actions is obliged to keep a limit which is two times more rigorous. Right away after three times crossing the acceptable limit of the dust value in the atmospheric air which is 50 micrograms per $\mathrm{m}^{3}$, meteorologists give signal so-called regulation. It means that large industrial companies must adapt to so-called rules of regulations and therefore limit their production to minimize emission of the pollutants. In Poland the regulation was not accepted and it has no use even in the period when the value of the dust significantly exceeds the allowed limit.

In the light of the presented arguments in the process of identification of the differences between Polish and Czech side concerning realisation of the projects, the following barriers appear (http//euroregions.org/files/ dokuments/Analiza...):

- high administrative burdens on the Polish side which characterise the fact that during applying project applications and during the inspection it is required to prepare many documents wherein some communities or enti- 
ties do not have sufficient processing capacity to elaborate and submit the project application,

- legislative differences,

- insufficient advisory and essential activity,

- more strict control of departments on the Czech side,

- problems with financing the projects characterising by lack of obtaining of payments on account on their realisation and long waiting periods on their reckoning up from 1 to 1.5 year,

- lack of database of potential partners interested in realisation of a specific cross-border project,

- languages' barriers,

- risk of exchange rate's differences.

The conducted survey among the beneficiaries of the realised projects showed that ratio of answers on the question: „How do you assess status and protection of the atmospheric air?" (Condition of the environment in the Silesian province in 2014) was as follows:

- the worst condition - 9\%,

- average condition - $79 \%$,

- the best condition - 6\%,

- there is no opinion - $6 \%$.

It seems that the presented results of the survey confirm the previously formulated conclusions regarding the emission of the pollutants and protection of the air on the Czech-Polish border.

\section{Summary}

Taking into account the above analysis it should be noticed positive changes in terms of emission of the harmful substances to the air which characterised in the fact that:

- the emissions were lower from the acceptable ones,

- emission indicators of the appropriate pollutions in the analysed period had decreasing tendency.

The pro-environmental investments done by the Czech and Polish side have contributed to the situation. Still occurring differences and barriers in the cross-border cooperation on various levels will require further normalization as a result of bilateral negotiations.

In Poland there is required quick and thorough modernization of the entire energetic system considering the appearing energy deficiency and its higher and higher prices, and especially: 
- saving of energy and improvement of efficiency of its use,

- reductions of transmission losses,

- supporting of renewable sources of energy,

- further reduction of the pollutants' emission to the atmosphere,

- gradual resigning of the carbon economy.

Realisation of the mentioned postulates should contribute to further improvement of the air quality and counteracting of changes of the climate. All these activities are consistent with the constitutional principle of the sustainable development and they serve economic and social growth.

\section{References}

Dzieje Cieszyna od pradziadów do czasów współczesnych, (2010). Książnica Cieszyńska.

Sońta W. ( 2008 ). Mienie komunalne w Polsce. Zagadnienia prawne i finansowe, Wydawnictwo Politechniki Radomskiej, Radom.

Ustawa z dnia 27.04. 2001 r. Prawo ochrony środowiska: t.j. Dz.U. 2013, poz.1232. Rozporządzenie Ministra Środowiska z dnia 10 sierpnia 2012 r. w sprawie stref, w których dokonuje się oceny jakości powietrza: Dz.U. 2012, poz. 914. Kaczmarczyk M. (2015). Niska emisja - od przyczyn występowania do sposobów eliminacji, Wydawnictwo Geosystem Burek, Kotysa s. c.

http//www. katowice. pios.gov.pl /raporty2014/raport2014.pdf

www.ec.cieszyn.pl

Dyrektywa 2004/8/WE Parlamentu Europejskiego i Rady z dnia 11.02.2004 r. w sprawie wspierania kogeneracji w oparciu o zapotrzebowanie na ciepło użytkowe na rynku wewnętrznym energii. Dostępne na: http//uokik.gov.pl http://euroregions.org/files/dokuments/Analiza/Analiza_Problemow_ver_ PL30092014_final.pdf

WIOŚ (2015). Stan środowiska w województwie śląskim w 2014 r. Katowice, Biblioteka Monitoringu Środowiska. 